\title{
A Checklist of Botanical Piscicides Available in Nigeria
}

\author{
E. A. Ekpendu, J. K. Saliu*, A. A. Otitoloju \\ Department of Zoology, University of Lagos, Lagos, Nigeria \\ Email: saliujk@yahoo.com
}

Received 20 March 2014; revised 20 April 2014; accepted 28 April 2014

Copyright (C) 2014 by authors and Scientific Research Publishing Inc.

This work is licensed under the Creative Commons Attribution International License (CC BY). http://creativecommons.org/licenses/by/4.0/

c) (†) Open Access

\section{Abstract}

The judicious use and rational management of biodiversity are predicated on the identification and documentation of various taxa. A field survey of botanical piscicides and their various uses was carried out in the six geopolitical zones of Nigeria. Six states, each from a geo-political zone of Nigeria, \{south-east (Imo State), south-west (Lagos State), north-west (Kaduna State), north-central (Benue State), north-east (Adamawa State) and south-south (Rivers State)\} were covered. Four local governments were selected from each of the six states as sampling locations, (a total of 24 local government areas). Luffa cylindrica, Carica papaya, Nicotiana tabacum, Anacardium occidenttale, Senna occidentalis, Raphia venifera, Musa acuminata, Vernonia amygdalina, Jatropha curcas, and Raphia venifera were common to all the areas investigated. Luffa cylindrica was the most frequently used botanical in Rivers, Lagos and Adamawa States $(27 \%, 28 \%$ and $24 \%$ ) respectively, Carica papaya in Kaduna State (24\%), and Nicotiana tabacum in Imo and Benue States $(28 \%$ and $22 \%)$ respectively. The least used botanicals across the states are Musa acuminata (2\%), Raphia venifera (4\%), Musa acuminata (2\%), Vernonia amygdalina (2\%), Jatropha curcas (3\%), and Raphia venifera (1\%), for Rivers, Imo, Kaduna, Lagos, Benue and Adamawa States respectively. A comprehensive documentation of our biodiversity will help in rational management and exploitation.

\section{Keywords}

Biodiversity, Botanical, Piscicides, Nigeria

\section{Introduction}

Plants from different families have been applied for catching fish all over the world [1]. Some plants contain

"Corresponding author. 
compounds of various classes that have insecticidal, piscicidal and molluscicidal properties [1]. The toxic parts of plants employed as fish poisons include the roots, seeds, fruits, barks or leaves [2]. Plant extracts used as piscicides in fisheries are considered advantageous when viewed against the backdrop of using persistent chemicals [1]. The active ingredients in the plant part used have varying potencies and modes of action depending on whether it is applied directly and in the form of extract, aqueous or alcohol used [1]. Exposure of fishes to botanicals may cause stress in the fishes without necessarily leading to death. Stress response is characterized by the biochemical and physiological changes which may be manifested in acute and chronic toxicity tests ([3]; in [1]). The phytochemistry of the plant revealed it contains flavinoids, saponins tannins, glycosides and alkaloids [4].

These plants are not only used as fish poisons or piscicides, but also used in spears and arrows for hunting and warfare as well as the traditional treatment of many diseases due to their anti-viral and anti-bacterial actions. Piscicidal plants are biodegradable, less severe than synthetic chemicals and are easily reversed in fish subjected to chronic concentration [5]. [6] observed that the piscicidal plants used in fishing actually act as stupefying agents and are excellent means of fishing which do not kill the whole fish stock like synthetic piscicides.

Good number of researchers have worked on the acute and sub acute toxicity of botanical piscicides, for instance, [7] studied the haematological characteristic of Clarias gariepinus juvenile exposed to powdered root of Derris elliptic, [1] worked on the haematology, plasma enzymes and organ indices of Clarias gariepinus after intra muscular injection with aqueous leaves extracts of lepidagathis alopecuroides. [8] examined the toxicity of methanol extract of Euphorbia lateriflora to the juvenile Clarias gariepinus. [9] studied the toxic effects of aqueous and ethanol extracts of Parkia biglobosa pods on Clarias gariepinus adults. [6] worked on the fish stupefying plants used by the Gond tribal of Mendha village of Central India.

However, much work has not been done on the survey of some of these botanical piscicides in Nigeria. Hence, this research is a deliberate effort to survey the variations in the use of some botanicals piscicides in Nigeria.

\section{Materials and Methods}

\subsection{Description of Study Areas and Sampling Locations}

The study areas consists of six states, each from a geo-political zone of Nigeria \{south-east (Imo State), southwest (Lagos State), north-west (Kaduna State), north-central (Benue State), north-east (Adamawa State) and south-south (Rivers State)\} (Figure 1). Four local governments were selected from each of the six states as sampling locations, a total of 24 local governments in all (Table 1). The local governments were randomly selected.

\subsection{Study Population and Sampling Design}

The study population comprises of all the fishermen in the four local governments of each of the six selected states of the geopolitical zones in Nigeria. This study covered the period between June, 2009 to March, 2013 and 2919 questionnaires were administered throughout the duration of this research. The questionnaires were validated by the Measurement and Evaluation Unit Educational Foundation Department, University of Lagos and were tested to be valid and reliable. Questionnaires were randomly distributed to 5\% of the total population of fishermen in each of the four selected Local Government Areas in the selected states from the six geo-political zones.

\section{Results and Discussion}

Ten botanicals were common to all the areas investigated and this included Luffa cylindrica, Carica papaya, Nicotiana tabacum, Anacardium occidentale, Senna occidentalis, Raphia venifera, Musa acuminata, Vernonia amygdalina, Jatropha curcas, and Raphia venifera (Figure 2). However, variations in the usage of the botanicals existed in the various states surveyed (Figures 3-12). Luffa cylindrica was the most used botanical in Rivers, Lagos and Adamawa States (27\%, 28\% and 24\%) respectively (Figure 6) Carica papaya in Kaduna State (24\%) (Figure 8), Nicotiana tabacum in Imo and Benue States (28\% and 22\%) respectively (Figure 5). The least used botanicals are Musa acuminata, Rivers and Kaduna States (2\%) respectively (Figure 12), Vernonia amygdalina, Lagos (2\%) (Figure 11), Jatropha curcas, Adamawa (2\%) (Figure 7), and Raphia venifera Adamawa (1\%) (Figure 9). The total percentage use of each of the botanicals in all the States are; Carica papaya (pawpaw) 98\%, Senna occidentalis (Yellow Flower) 59\%, Anacardium occidentale (Cashew) 81\%, Nicotiana tabacum (tobacco) 


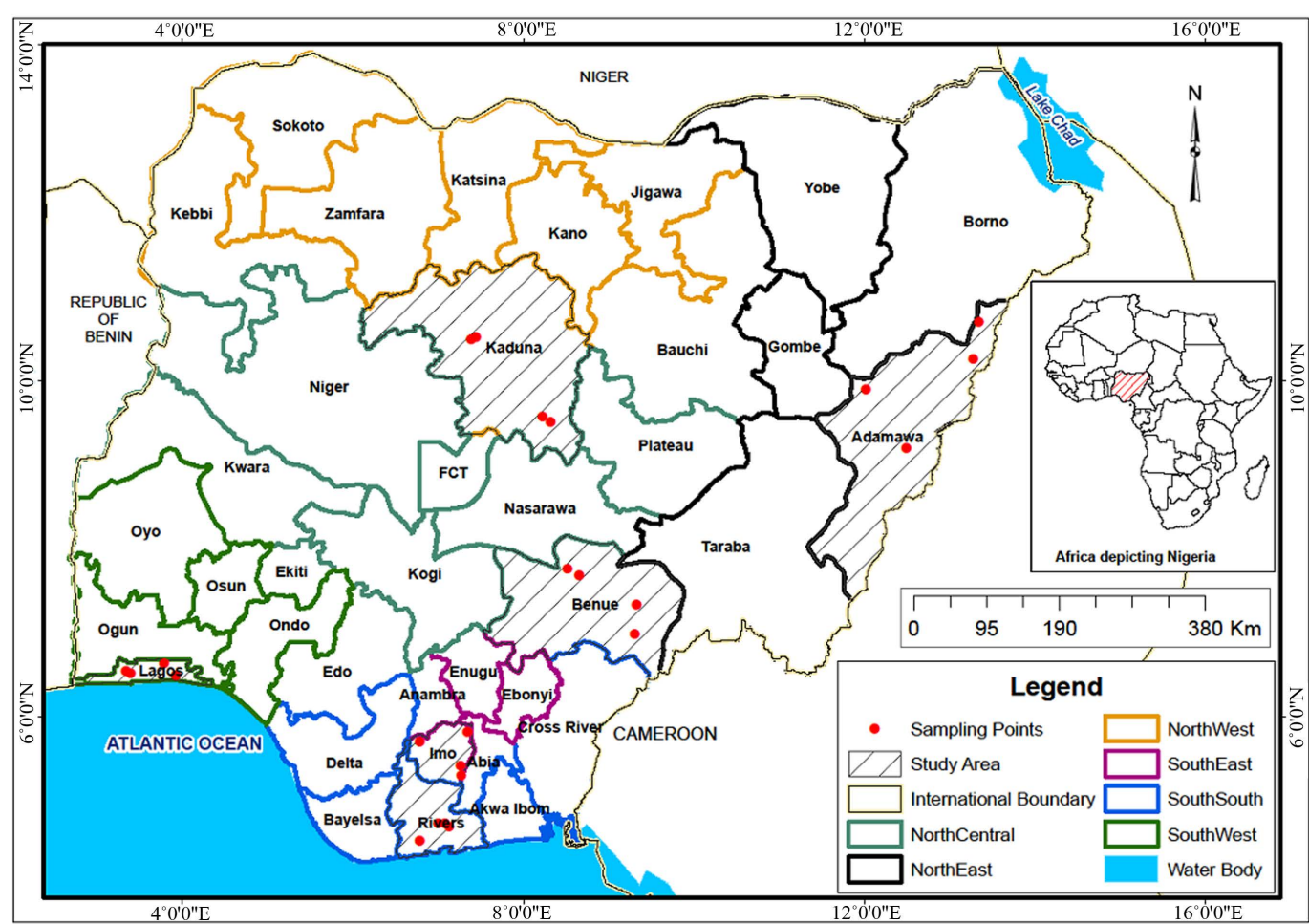

Figure 1. Map of Nigeria showing the sampling points in the six geopolitical zones.

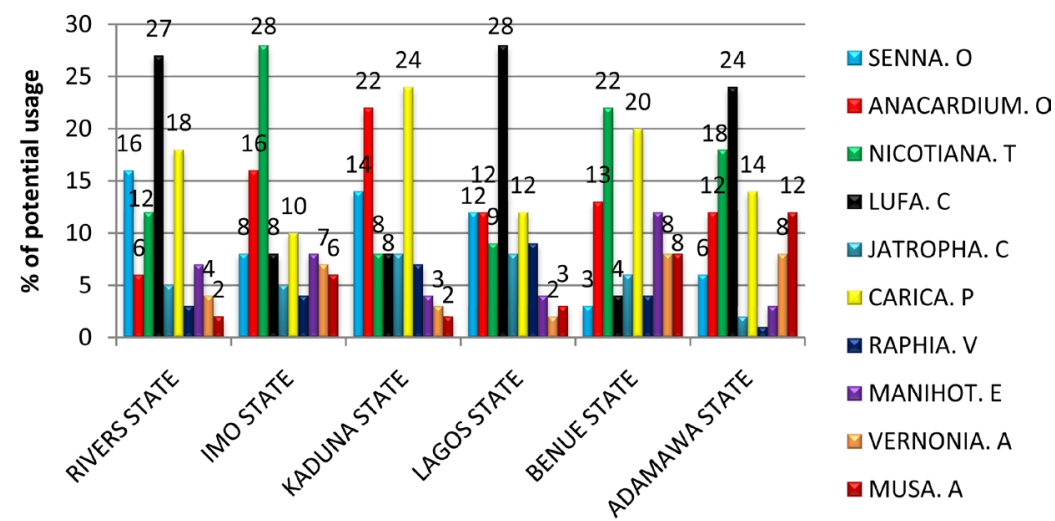

Figure 2. Percentage use of the ten botanicals in the selected states from the six geopolitical zones in Nigeria.

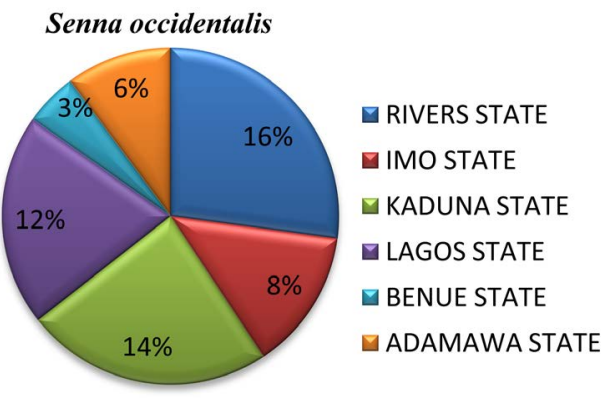

Figure 3. Percentage use of Senna occidentalis in the selected states from the six geopolitical zones of Nigeria. 


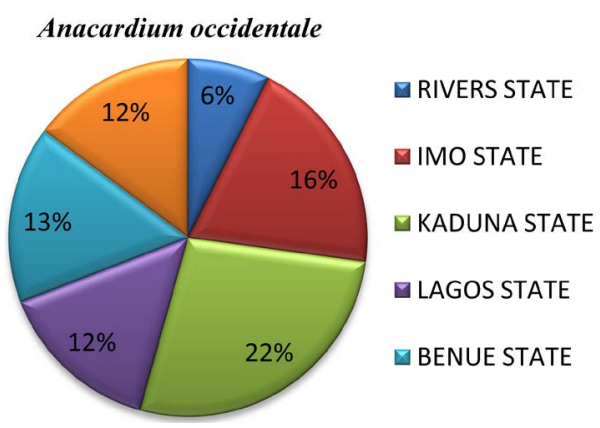

Figure 4. Percentage use of Anacardium occidentale in the selected states from the six geopolitical zones of Nigeria.

Table 1. Sampling locations and their GPS.

\begin{tabular}{|c|c|c|}
\hline State/Local Government & Town & GPS \\
\hline KADUNA STATE Jemaa & Kafanchan & $9^{\circ} 34^{\prime} 59.49^{\prime \prime} \mathrm{N}, 8^{\circ} 17 ' 26.41 " \mathrm{E}$ \\
\hline Kaduna North & Angwan Muazu & $10^{\circ} 15^{\prime} 58.42^{\prime \prime} \mathrm{N}, 7^{\circ} 06^{\prime} 46.96^{\prime \prime} \mathrm{E}$ \\
\hline Kaduna South & Kakuri & $10^{\circ} 28^{\prime} 03.22^{\prime \prime} \mathrm{N}, 7^{\circ} 24^{\prime} 40.52^{\prime \prime} \mathrm{E}$ \\
\hline Zagon Katab & Angwanrimi & $11^{\circ} 04^{\prime} 54.65^{\prime \prime} \mathrm{N}, 7^{\circ} 42^{\prime} 52^{\prime \prime} \mathrm{E}$ \\
\hline LAGOS STATE Lagos Mainland & Unilag & $6^{\circ} 29^{\prime} 51.50^{\prime \prime N}, 3^{\circ} 23^{\prime} 03.32^{\prime \prime E}$ \\
\hline Epe & Epe & $6^{\circ} 37^{\prime} 19.00 " \mathrm{~N}, 3^{\circ} 19^{\prime} 00.01^{\prime \prime E}$ \\
\hline Oshodi-Isolo & Okota & $6^{\circ} 30^{\prime} 42.09^{\prime \prime} \mathrm{N}, 3^{\circ} 18^{\prime} 45.42^{\prime \prime} \mathrm{E}$ \\
\hline Eti Osa & Epe Ibeju & $6^{\circ} 26^{\prime} 55.32^{\prime \prime N}, 3^{\circ} 33^{\prime} 03.27^{\prime \prime E}$ \\
\hline RIVERS STATE Eleme & Rumuomasi & $4^{\circ} 49^{\prime} 43.19^{\prime \prime N}, 7^{\circ} 01 ' 32.31 " \mathrm{E}$ \\
\hline Port Harcourt City Council & Isaac Boroh Street & $4^{\circ} 47^{\prime} 28.43^{\prime \prime N}, 7^{\circ} 00 ' 16.16^{\prime \prime} \mathrm{E}$ \\
\hline Degema & Degema & $4^{\circ} 46^{\prime} 10.27^{\prime \prime N}, 6^{\circ} 46^{\prime} 05.38 " \mathrm{E}$ \\
\hline Tai & Rumuola & $4^{\circ} 49^{\prime} 44.33^{\prime \prime} \mathrm{N}, 6^{\circ} 59^{\prime} 55.0^{\prime \prime} \mathrm{E}$ \\
\hline IMO STATE Oguta & Oguta & $5^{\circ} 42^{\prime} 55.20^{\prime \prime} \mathrm{N}, 6^{\circ} 48^{\prime} 13.12^{\prime \prime} \mathrm{E}$ \\
\hline Aboh-Mbaise & Umuogu-Amuza & $5^{\circ} 21^{\prime} 50.98 " \mathrm{~N}, 7^{\circ} 16^{\prime} 46.56^{\prime \prime} \mathrm{E}$ \\
\hline Ngor Okpala & Okpala & $5^{\circ} 18^{\prime} 43.26^{\prime \prime N}, 7^{\circ} 15^{\prime} 45.30^{\prime \prime} \mathrm{E}$ \\
\hline Okigwe & Okigwe & $5^{\circ} 49^{\prime} 00.05^{\prime \prime N}, 7^{\circ} 21^{\prime} 00.00^{\prime \prime} \mathrm{E}$ \\
\hline BENUE STATE Katsina-ala & Katsina-ala & $9^{\circ} 34^{\prime} 59.49 " \mathrm{~N}, 8^{\circ} 17^{\prime} 26.41^{\prime \prime E}$ \\
\hline Kwande & Kwande & $10^{\circ} 15^{\prime} 58.42^{\prime \prime} \mathrm{N}, 7^{\circ} 06^{\prime} 46.96^{\prime \prime} \mathrm{E}$ \\
\hline Makurdi & Wurukum & $10^{\circ} 28^{\prime} 03.22^{\prime \prime} \mathrm{N}, 7^{\circ} 24^{\prime} 40.52^{\prime \prime} \mathrm{E}$ \\
\hline Tarka & Moun & $11^{\circ} 04^{\prime} 54.65^{\prime \prime} \mathrm{N}, 7^{\circ} 42^{\prime} 52^{\prime \prime} \mathrm{E}$ \\
\hline ADAMAWA STATE Shelleng & Shelleng & $6^{\circ} 29^{\prime} 51.50 " \mathrm{~N}, 3^{\circ} 23^{\prime} 03.32^{\prime \prime} \mathrm{E}$ \\
\hline Michika & Wuron Bayi & $6^{\circ} 37^{\prime} 19.00 " \mathrm{~N}, 3^{\circ} 19^{\prime} 00.01^{\prime \prime} \mathrm{E}$ \\
\hline Mubi North & Mubi & $6^{\circ} 30^{\prime} 42.09 " \mathrm{~N}, 3^{\circ} 18^{\prime} 45.42^{\prime \prime} \mathrm{E}$ \\
\hline Yola South & Wuro Hausa & $6^{\circ} 26^{\prime} 55.32^{\prime \prime N}, 3^{\circ} 33^{\prime} 03.27 " \mathrm{E}$ \\
\hline
\end{tabular}




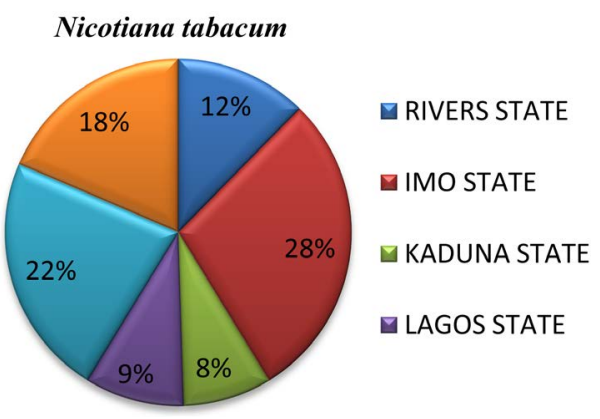

Figure 5. Percentage use of Nicotiana tabacum in the selected states from the six geopolitical zones of Nigeria.

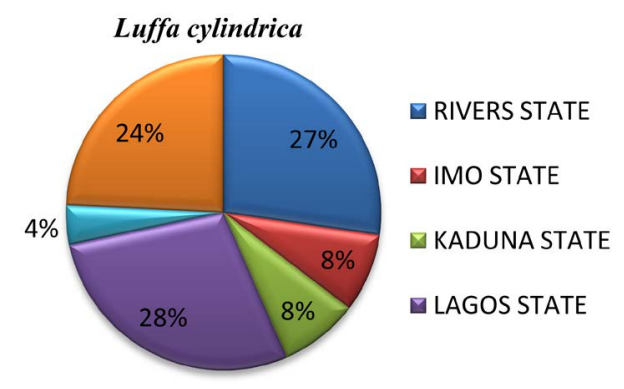

Figure 6. Percentage use of Luffa cylindrica in the selected states from the six geopolitical zones of Nigeria.

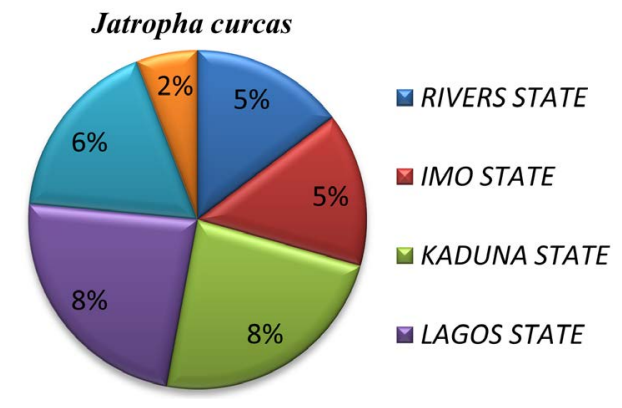

Figure 7. Percentage use of Jatropha curcas in the selected states from the six geopolitical zones of Nigeria.

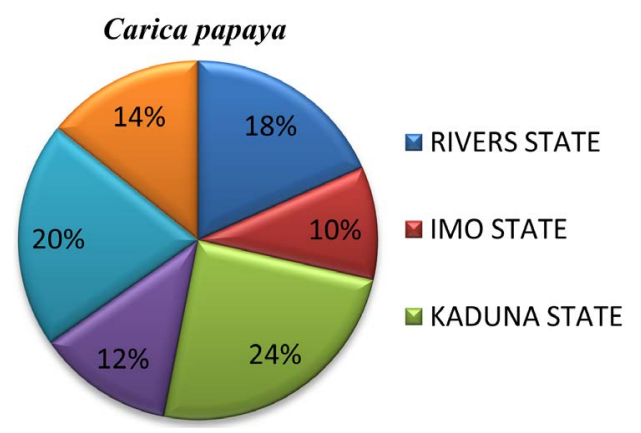

Figure 8. Percentage use of Carica papaya in the selected states from the six geopolitical zones of Nigeria. 


\section{Raphia venifera}

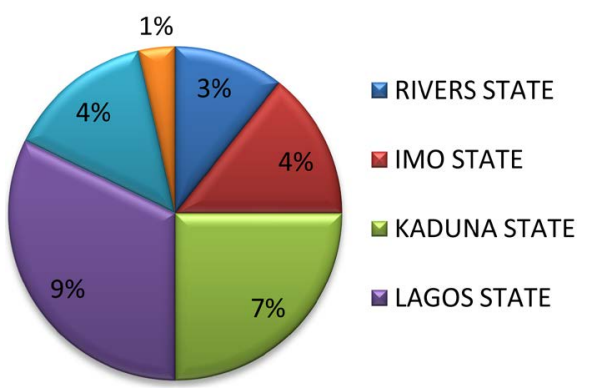

Figure 9. Percentage use of Raphia vinifera in the selected states from the six geopolitical zones of Nigeria.

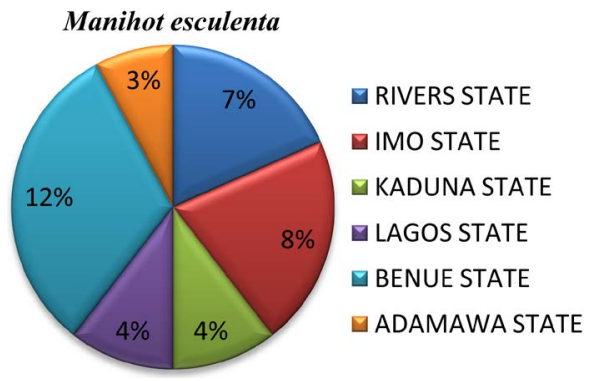

Figure 10. Percentage use of Manihot esculenta in the selected states from the six geopolitical zones of Nigeria.



Figure 11. Percentage use of Vernonia amygdalina in the selected states from the six geopolitical zones of Nigeria.

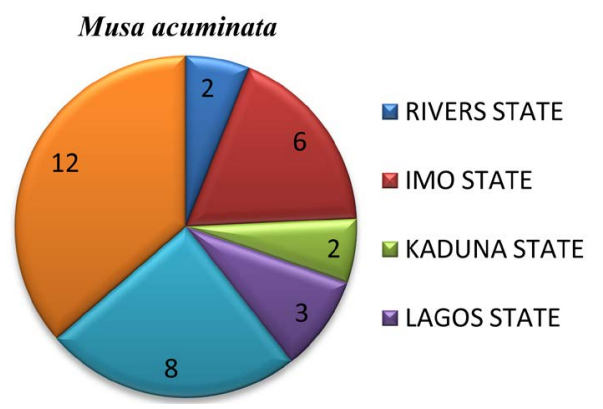

Figure 12. Percentage use of Musa acuminata in the selected states from the six geopolitical zones of Nigeria. 
97\%, Luffa cylindrica (sponge plant) 99\%, Jatropha curcas (physics plant) 34\%, Raphia vinifera (Raphia palm) 28\%, Manihot esculenta (cassava) 38\%, Vernonia amygdalina (bitter leaf) 32\%, Musa acuminata (plantain) $33 \%$.

The variations in the usage of the botanical piscicides across the geopolitical zones of Nigeria were largely dependent on the history and culture of the people inhabiting each zone. The use of poisonous botanicals in hunting and fishing is not particularly a new development; it is almost as old as our ancestors [10]. However, advances in piscicide science include the documentation of plant taxa so used, phyto-chemical analyses to isolate the active ingredients, determining the mode of actions on target fishes, their joint toxicities, reversibility's and potentials for selective use.

In developed countries, plant taxa with piscicidal activities have been well documented. These is however not so in their developing counterparts.

[11] gave a checklist of piscicidal plants in North America, South America and Australia. In North America these are; Black Walnut (Juglans nigra), devil's Shoestring (Symphoricarpos orbiculatus), Horse Chestnut (Aesculus hippocastanum L.), Polk Sallet/Polkweed (Phytolacca americana), Turkey-Mullein (Eremocarpus setigerus), California Buckeye (Aesculus california), Soap plant (Chlorogalum pomeridianum), Indian hemp (Apocynum cannabinum), Pokeweed/Polk sallet (Phytolacca americana), Indian Turnip (Arisaema triphyllum), Wild cucumber/Manroot (Marah fabaceus).

In South America, they include; Lechuguilla (Agave lechuguilla), Soapberry (Sapindus drummondii), Mexican Buckeye (Ungnadia speciosa), Barbasco (Jacquinia sprucei), Barbasco, (Tephrosia toxicofera), Barbasco (Lonchocarpus nicou), Acariquara, (Minquartia guianensis), Fish poison leaves (Euforbia cotinifolia). Pacific Islands; Fish poison tree (Barringtonia asiatica), the fish poison plant (Wikstroemia uva-ursi).

In Australia, they include: Pituri (Duboisia hopwoodii), Austral indigo (Indigofera australis), fish killer tree (Barringtonia asiatica), fish poison tree (Acacia ditricha), fish poison tree (Barringtonia racemosa), fish poisonwood (Barringtonia vitiflora), fish poison wattle/soapy wattle (Acacia holosericea). India: Indian beech (Pongamia pinnata), fish berries (Anamirta cocculus), swallowwort (Asclepias curassavica).

In Philippine, [12] documented ten locally available piscicidal plants. The ampalaya (Momordica charantia), adelfa (Nerium indicum), agave (Agave cantala), kalamansi (Citrus mitis), lagundi (Vitex negundo), madre de cacao (Gliricidia sepium), makabuhai (Tinosphora rhumpii), neem (Azadirachta indica), physic nut (Jatropa curcas) and sambong (Blumea balsamifera).

In Nigeria, [2] identified Achyranthes aspera, Anacardium occidentale, Pieralima nitida, Rauvolfia vomitoria, Strophathus sarmentosus, Thevetia neriifolia, Kigelia africana, Synphytum tuberosum, Pachylobus edulis, Senna alecandrina, Erythrophleum suaveolens, Alchronea cordifolia, Ricinus communis, Bridelia micrantha, Entanda abyssinica, Acacia sieberena, Parkia biglobosa as piscicidal plants from southwest Nigeria.

Botanicals are natural biocides [13]. They are of medicinal importance [14] and possess anti microbial activity [4]. They are also used as molluscicides [15]. The young stem of the plants are used as toothbrush as well as to clean the tongue in the treatment of thrush [16]. These plants because of their significant contributions to humans should be well documented as a prelude to their rational management and exploitation.

\section{Acknowledgements}

I wish to acknowledge Dr. E. U. Okoli of the Measurement and Evaluation Unit, Educational Foundation Department, Faculty of Education, University of Lagos, Nigeria.

\section{References}

[1] Gabriel, U.U., Obomanu, F.G. and Edori, O.S. (2009) Haematology, Plasma Enzymes and Organ Indices of Clarias gariepinus after Intramuscular Injection with Aqueous Leaves Extracts of Lepidagathis alopecuroides. African Journal of Biochemistry Research, 3, 312-316.

[2] Fafioye, O.O. (2005) Plants with Piscicidal Activities in Southwestern Nigeria. Turkish Journal of Fisheries and Aquatic Sciences, 5, 91-97.

[3] Singh, S.K. and Singh, A. (2002) Toxic Effect of Euphorbia pulcherima Plant to Fingerlings of Labeo rohita (Hamilton) in Different Culturing Conditions. World Journal of Fish and Marine Sciences, 1, 324-329.

[4] Obomanu, F.G., Fekarrurhobo, G.K. and Howard, I.C. (2005) Atimicrobial Activity of Extracts of Leaves of Lepidagathis alopecuroides (Vahl). Journal of Chemical Society of Nigeria, 30, 33-35. 
[5] Kela, S.L., Ogunsusi, R.A., Ogbogu, V.C. and Nwude, N. (1989) Screening of Some Plants for Molluscicidal Activity. Revue, Eled. Med. Vet. Physc. Trop., 42, 195-202.

[6] Kamalkishor, H.N. and Kulkani, K.M. (2008) Fish Stupefying Plants Used by the Gond Tribal of Mendha Village of Central India, Indian. Journal of Traditional Knowledge, 8, 531-534.

[7] Olufayo, M.O. (2009) Hematological Characteristics of Clarias gariepinus Juveniles Exposed to Derris Elliptica Root Powder. African Journal of Food Agriculture Nutrition and Development, 9, 920-933.

[8] Usman, J.I., Auta, J., Adamu, A.K. and Abubakar, M.S. (2005) Toxicity of Methanol Extract of Euphorbia lateriflora to the Juvenile of Clarias gareipinus. Chem Class Journal, 2, 59-61.

[9] Abalaka, S.E. and Auta, J. (2010) Toxic Effects of Aqueous and Ethanol Extracts of Parkia biglobosa Pods on Clarias gariepinus Adults. World Journal of Biological Research, 3, 9-17.

[10] Finlayson, B.J., Schnick, R.A., Cailteux, R.L., DeMong, L., Horton, W.D., McClay, W. and Thompson, C.W. (2002) Assessment of Antimycin as Use in Fisheries and Its Potential for Reregistration. Fisheries, 27, 10-18.

[11] Chuck, K. (2003) Fishing with Poison. The Bulletin of Primitive Technology, 25, 277-301. http://dx.doi.org/10.1577/1548-8446(2002)027<0010:AOAAUI>2.0.CO;2

[12] Arsenia, G.C. and Fajardo, L.J. (2004) Evaluation of Botanical Piscicides on Nile Tilapia. 6th International Symposium on Tilapia Aquaculture, Manila, 179-187.

[13] Ernest Hodgson (2004) A Textbook of Modern Toxicology. 3rd Edition, John Wiley and Sons, Hoboken.

[14] Adesina, S.K. (1982) Studies on the Nigerian Herbal Anticonvulsant Recipe. International Journal of Crude Drug Resources, 20, 93-100.

[15] Singh, D. and Singh, S.K. (2005) Molluscicidal of Three Common Plants from India. Fitoterapia, 76, 747-751. http://dx.doi.org/10.1016/j.fitote.2005.08.002

[16] Ogundare, A.O. (2007) Antimicrobial Effects of Tithonia diversifolia and Jatropha gossypifolia Leaf Extracts. Trends in Applied Sciences Research, 2, 145-150. http://dx.doi.org/10.3923/tasr.2007.145.150 